\title{
Some effects of growth conditions on steady state and heat shock induced htpG gene expression in continuous cultures of Escherichia coli
}

\author{
A. Heitzer, C. A. Mason, M. Snozzi, and G. Hamer \\ Swiss Federal Institute of Technology, Institute of Aquatic Sciences, Ueberlandstrasse 133, CH-8600 Dübendorf, Switzerland
}

Received May 3, 1990/Accepted August 28, 1990

\begin{abstract}
Most of the data concerning heat shock gene expression reported in the literature are derived from batch culture experiments under substrate and nutrient sufficient conditions. Here, the effects of dilution rate and medium composition on the steady state and heat shock induced htpG gene expression have been investigated in continuous cultures of Escherichia coli, using a chromosomal htpG-lacZ gene fusion. During steady state growth temperature dependent patterns of the relative htpG expression were found to be largely similar, irrespective of the growth condition. However, nitrogen-limited growth resulted in a markedly reduced specific steady state htpG expression as compared to growth under carbon limitation or in complex medium, correlating qualitatively with the total cellular protein content. During heat shock, tight temperature controlled expression was evident. While the relative heat shock induced expression was largely identical at various dilution rates in a given growth medium, significantly different response patterns were observed in the three growth media at any given dilution rate. From these results a clearly temperature regulated htpG expression during both, steady and transient state growth in continuous culture is evident. which is further significantly affected by the growth condition used.
\end{abstract}

Key words: Temperature - Heat shock gene expression - htpG - Heat shock protein - Escherichia coli - Continuous culture - Dilution rate - Growth medium

Spatial and temporal heterogeneity of physical and chemical conditions are not only encountered in natural environments but also, depending on both scale and type of process, in technical bioreactor systems. One conse-

Offprint requests to: $\mathrm{G}$. Hamer quence of this is that complex transient physiological response patterns can result in the microbes involved. Of the various physical environmental parameters, temperature has for a long time been of major interest, due to its importance as a major control parameter for process optimization and also because of the fluctuations found in natural environments.

Bacterial metabolism is affected in many ways by thermally mediated reversible or irreversible structural alterations to macromolecular cellular components. The overall macroscopic response of a growing bacterial culture to such structural alterations resulting from heat shocks is seen as transient changes in the growth rate, which has been shown to vary depending on the exposure time and magnitude of the heat shock (Heitzer and Hamer 1990). A highly coordinated adaptive response has also been shown to occur in all bacteria so far investigated as a result of temperature increases within the optimum and superoptimum temperature ranges for growth. This heat shock response involves an increase in the synthesis rates of a set of specific proteins. Whilst in Escherichia coli 18 such heat shock proteins have been described (Neidhardt and Van Bogelen 1987; Raina and Georgopoulos 1990), their functions are only partially known. The presence of these proteins at all growth temperatures (Herendeen et al. 1979; Neidhardt et al. 1984) suggests a more fundamental role in cellular metabolism, than simply a function related to adverse environmental temperature conditions. Involvement in processes such as protein degradation (Goff et al. 1984), cell division (Tsuchido et al. 1986), macromolecular synthesis and protein assembly (Neidhardt and Van Bogelen 1987; Goloubinoff et al. 1989; Van Dyk et al. 1989) have been reported. The heat shock response is under the positive control of the rpoH gene (Neidhardt and Van Bogelen 1981; Yamamori and Yura 1982), which codes for a RNA-polymerase sigma factor, $\sigma^{32}$ (Grossman et al. 1984). The holoenzyme associated with $\sigma^{32}$ selectively recognizes the promoters of heat shock genes (Grossman et al. 1984; Cowing et al. 1985). Here we describe work using one of these heat shock genes, htpG, which codes 
for the C62.5 protein. This protein represents ca. $0.26 \%$ of the total cellular protein of $E$. coli during exponential growth at $37^{\circ} \mathrm{C}$ (Neidhardt et al. 1984). Although the amino acid sequence of this protein is highly conserved amongst eukaryotes and prokaryotes (Bardwell and Craig 1987) its precise function in prokaryotes is still unknown (Bardwell and Craig 1988).

Most of the data concerning heat shock gene expression and associated protein synthesis reported in the literature are derived from exponentially growing batch cultures under substrate and nutrient sufficient conditions. Here, our interest was in the expression pattern of the htpG heat shock gene at various imposed growth (dilution) rates in continuous culture with a defined glucose/mineral salts medium. Using a chromosomal htpG-lacZ gene fusion, the effects of heat shocks under either carbon- or nitrogen-limited growth could be investigated. Further, the effects of medium composition (nutrient status) on the heat shock response pattern of the continuous culture are also compared with growth in a complex medium.

\section{Materials and methods}

\section{Organism}

Escherichia coli $J B 23$. This strain was kindly provided by Dr. E. A. Craig. It contains a chromosomal substitution deletion mutation where the coding sequence of the htpG gene has been replaced by the coding sequence of the lacZ gene in a $\mathrm{Lac}^{-}$mutant, resulting in an in frame fusion between the codons for amino acid 15 of C62.5 and amino acid 8 of $\beta$-galactosidase, called $\Delta$ htpG1::lacZ. A detailed description of the strain and its construction is given by Bardwell and Craig (1988).

\section{Growth conditions}

$E$. coli $J B 23$ was grown in continuous culture in a defined mineral salts medium (Evans et al. 1970) modified by replacing citric acid by $55 \mathrm{mg} \mathrm{Na}$ EDTA/l. For carbon limited growth $1 \mathrm{~g}$ glucose $/ 1$ served as the sole carbon energy source. Nitrogen limitation was attained by using a molar carbon to nitrogen ratio of $16.67: 1$. Ammonium chloride was the nitrogen source. For experiments in a complex medium, the same Evans salts medium was supplemented with $0.5 \mathrm{~g}$ glucose $/ 1,0.5 \mathrm{~g}$ yeast extract $/ 1$ and $0.5 \mathrm{~g}$ brain heart infusion/l. An antifoam agent, $20 \mathrm{mg}$ polypropylene glycol/1, was added to all media.

\section{Bioreactor}

The bioreactor used was a computer controlled 2.51 total volume minibioreactor (MBR BioReactor AG, Wetzikon, Switzerland) with an operatıng volume of 1.81 . For cultivation the temperature was maintained at 32,37 or $42^{\circ} \mathrm{C}$. The stirrer speed was $800 \mathrm{rev} / \mathrm{min}$ and the air flow rate used was $501 / \mathrm{h}$. The $\mathrm{pH}$ was maintaned constant at 7.0 by the controlled addition of either an equimolar $1 \mathrm{~N} \mathrm{NaOH} / \mathrm{KOH}$ or a $10 \% \mathrm{H}_{3} \mathrm{PO}_{4}$ solution. Medium was continuously pumped into the reactor at a constant flow rate and spent medium was removed by an outlet pump controlled by the weight of the bioreactor.

\section{Heat treatment}

To subject the culture in the bioreactor to defined heat shocks, programmed temperature profiles involving changes from 37 to $42^{\circ} \mathrm{C}$ for 5,10 and $15 \mathrm{~min}$ exposure time were used. The times required for heating to and cooling from the higher temperature were $2 \mathrm{~min}$. Experiments were carried out at dilution rates of 0.23 , 0.41 and $0.63 \mathrm{~h}^{-1}$.

\section{Sampling}

For dry weight measurements duplicate $5 \mathrm{ml}$ samples were filtered through pretared, $0.2 \mu$ pore diameter Nuclepore filters (Nuclepore, Pleasanton, USA), dried to constancy and weighed. For the enzyme assay $5 \mathrm{ml}$ samples were immediately frozen in liquid nitrogen and stored on ice.

\section{Enzyme assay}

Frozen cells were thawed below $4^{\circ} \mathrm{C}$, washed once with $0.02 \mathrm{M}$ $\mathrm{Na}_{2} \mathrm{HPO}_{4}$ buffer $\mathrm{pH} 7$ by centrifugation at $36000 \mathrm{~g}$ for 6 min at $4^{\circ} \mathrm{C}$ and resuspended in the same buffer. The cells were then disrupted by sonication at $0^{\circ} \mathrm{C}$ and kept on ice prior to assaying. $\beta$-galactosidase was assayed according to the procedure described by Miller (1972), modified such that the rate of increase in the absorbance at $420 \mathrm{~nm}$ was measured. Relative specific activities are expressed in arbitrary units and defined as enzyme activity per unit dry mass, divided by the specific activity during steady state growth.

\section{Protein}

The cellular protein content was determined according to a modified Buret procedure described by Munkres and Richards (1965). The absorbance of the samples at $300 \mathrm{~nm}$ was compared to a bovine serum albumin standard.

All the experiments were carried out in triplicate in at least two independent series.

\section{Results}

The relative htpG expression levels during steady state growth of Escherichia coli at 32,37 and $42^{\circ} \mathrm{C}$ in carbonlimited, nitrogen-limited and complex medium are given in Table 1. In the three growth media used an essentially similar temperature dependent response was observed. In

Table 1. Relative htpG heat shock gene expression levels during steady state growth of $E$. coli at different temperatures under various growth conditions

\begin{tabular}{|c|c|c|c|c|}
\hline \multicolumn{2}{|l|}{ Growth conditions } & \multicolumn{3}{|c|}{$\begin{array}{l}\text { Relative htpG gene expression } \\
\text { Growth temperature }\left[{ }^{\circ} \mathrm{C}\right]\end{array}$} \\
\hline $\begin{array}{l}\text { Growth } \\
\text { medium }\end{array}$ & $\begin{array}{l}\text { Growth } \\
\text { rate }\left[\mathrm{h}^{-1}\right]\end{array}$ & 32 & 37 & 42 \\
\hline Carbon-limited & $\begin{array}{l}0.23 \\
0.41\end{array}$ & $\begin{array}{l}0.50 \\
0.44\end{array}$ & $\begin{array}{l}1 \\
1\end{array}$ & $\begin{array}{l}1.82 \\
1.99\end{array}$ \\
\hline Nitrogen-limited & 0.41 & 0.62 & 1 & 1.94 \\
\hline Complex-medium & 0.41 & 0.49 & 1 & 1.84 \\
\hline
\end{tabular}




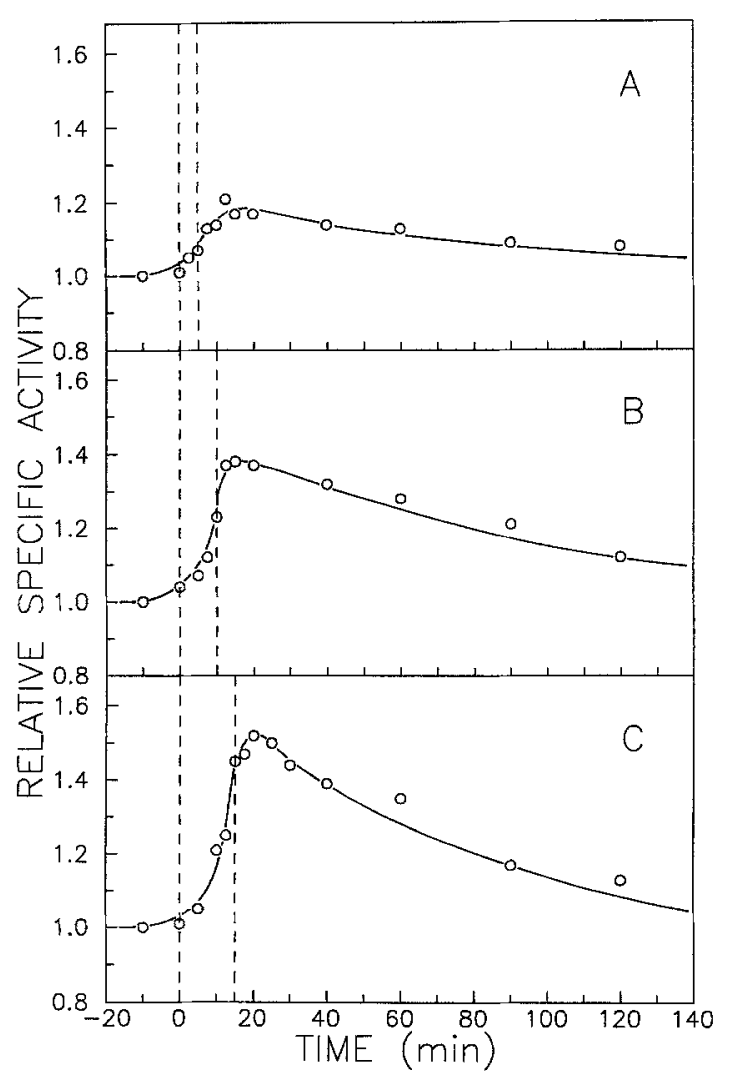

Fig. 1A-C. Effect of heat shock exposure time on the relative specific htpG gene expression in $E$, coli growing carbon-limited in continuous culture at a dilution rate of $0.23 \mathrm{~h}^{-1}$. The growth and heat shock temperatures were 37 and $42^{\circ} \mathrm{C}$ respectively, heat shock exposure times were $5 \mathrm{~min}(\mathbf{A}), 10 \mathrm{~min}(\mathbf{B})$ and $15 \mathrm{~min}(\mathbf{C})$, and are marked by the dashed lines

order to determine the effect of heat shock exposure time on htpG gene expression, cultures growing carbonlimited at $37^{\circ} \mathrm{C}$ at a dilution rate of $0.23 \mathrm{~h}^{-1}$ were subjected to heat shocks at $42^{\circ} \mathrm{C}$ for 5,10 and $15 \mathrm{~min}$. The results, shown in Fig. 1, indicate that increasing the exposure time resulted in higher final levels of the relative specific $\beta$-galactosidase activity for the exposure times investigated. The increase in intracellular $\beta$-galactosidase levels, i.e., $8 \%$ after $5 \mathrm{~min}, 23 \%$ after $10 \mathrm{~min}$ and $45 \%$ after $15 \mathrm{~min}$ showed that proportionality between exposure time and htpG gene expression level did not exist. When the culture was returned to $37^{\circ} \mathrm{C}$ after each heat shock an immediate reduction of htpG gene expression was observed. By comparing the expected half lives of $\beta$-galactosidase, assuming a basal expression level equivalent to the pre-heat shock steady state condition, with the observed values at different exposure times it is evident that the reduction of the intracellular level of $\beta$-galactosidase after the heat shock was not solely due to a growth rate dependent intracellular dilution effect (Table 2).

Changes in the relative specific $\beta$-galactosidase levels for cultures growing at $37^{\circ} \mathrm{C}$ at three different dilution rates, when subjected to a 10 -min heat shock at $42^{\circ} \mathrm{C}$, were measured. The relative response patterns during the
Table 2. Half life times $\left(t_{1 / 2}\right)$ for the htpG-lacZ fusion protein in $E$. coli after various heat shocks at $42^{\circ} \mathrm{C}$ under different growth conditions; for definition of half life time see text

\begin{tabular}{|c|c|c|c|c|}
\hline \multicolumn{3}{|c|}{ Growth/Heat shock conditions } & \multicolumn{2}{|c|}{$\begin{array}{l}\text { Half life time for the } \\
\text { htpG-lacZ fusion protein }\end{array}$} \\
\hline $\begin{array}{l}\text { Growth } \\
\text { medium }\end{array}$ & $\begin{array}{l}\text { Growth } \\
\text { rate } \\
{\left[\mathrm{h}^{-1}\right]}\end{array}$ & $\begin{array}{l}\text { Heat } \\
\text { shock time } \\
\text { [min] }\end{array}$ & $\begin{array}{l}t_{1 / 2} \\
\text { expected } \\
{[\mathrm{min}]}\end{array}$ & $\begin{array}{l}t_{1 / 2} \\
\text { observed } \\
{[\mathrm{min}]}\end{array}$ \\
\hline $\begin{array}{l}\text { Carbon- } \\
\text { limited }\end{array}$ & $\begin{array}{l}0.23 \\
0.23 \\
0.23 \\
0.41 \\
0.63\end{array}$ & $\begin{array}{r}5 \\
10 \\
15 \\
10 \\
10\end{array}$ & $\begin{array}{r}181 \\
181 \\
181 \\
101 \\
66\end{array}$ & $\begin{array}{l}90 \\
75 \\
55 \\
35 \\
20\end{array}$ \\
\hline $\begin{array}{l}\text { Nitrogen- } \\
\text { limited }\end{array}$ & 0.41 & 10 & 101 & 40 \\
\hline $\begin{array}{l}\text { Complex- } \\
\text { medium }\end{array}$ & 0.41 & 10 & 101 & 35 \\
\hline
\end{tabular}

Table 3. Effect of dilution rate on steady state and heat shock induced specific htpG gene expression expressed as specific $\beta$ galactosidase activity in $E$. coli in a carbon-limited glucose mineral salts medium. The growth and heat shock temperatures were 37 and $42^{\circ} \mathrm{C}$ respectively, heat shock exposure was $10 \mathrm{~min}$

\begin{tabular}{|c|c|c|c|}
\hline \multirow[b]{2}{*}{ Dilution rate $\left[\mathrm{h}^{-1}\right]$} & \multicolumn{3}{|c|}{$\begin{array}{l}\text { Specific } \beta \text {-galactosidase activity } \\
{\left[\Delta \mathrm{OD}_{420} / \mathrm{g}_{\mathrm{cells}} \cdot \mathrm{min}\right]}\end{array}$} \\
\hline & 0.23 & 0.41 & 0.63 \\
\hline Steady state level (A) & 1656 & 1503 & 1350 \\
\hline $\begin{array}{l}\text { Increase during } \\
10 \text { min heat shock (B) }\end{array}$ & 340 & 313 & 283 \\
\hline Ratio (A/B) & 4.87 & 4.80 & 4.77 \\
\hline
\end{tabular}

heat shock were identical but the subsequent reduction patterns differed markedly, showing a degree of dilution rate dependence. The results presented in Table 2 show significant discrepancies between observed and expected half life times. Table 3 shows that the specific $\beta$-galactosidase activities during steady state growth decreased with increasing dilution rate and that during a 10 -min heat shock the increase in $\beta$-galactosidase level that occurred was proportional as illustrated by the constant ratios.

To investigate whether either the nature of the limitation in a defined mineral medium or use of a complex medium affected expression patterns, experiments under carbon and nitrogen limitation and with a complex medium were carried out at $37^{\circ} \mathrm{C}$ and a dilution rate of $0.41 \mathrm{~h}^{-1}$ that involved a 10 -min heat shock at $42^{\circ} \mathrm{C}$. The results are shown in Fig. 2 . The difference between the relative specific $\beta$-galactosidase activities during steady state and immediately after heat shock was ca. $40 \%$ under nitrogen limitation, ca. $20 \%$ during carbon limitation and ca. $30 \%$ in the complex medium. In addition, the specific activities observed depended on the medium used 


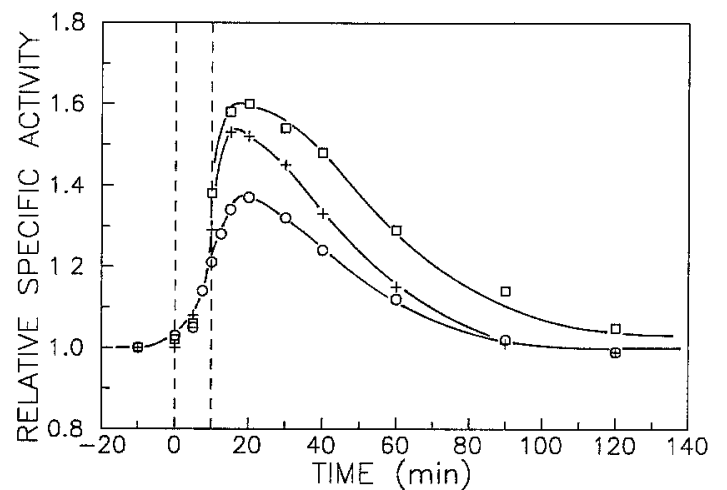

Fig. 2. Effect of growth medium composition on the relative specific htpG gene expression in $E$. coli growing either carbon-limited $(O)$ or nitrogen-limited $(\square)$ in a glucose mineral salts medium and in a complex medium (+) at a dilution rate of $0.41 \mathrm{~h}^{-1}$. The growth and heat shock temperatures were 37 and $42^{\circ} \mathrm{C}$ respectively, heat shock exposure was $10 \mathrm{~min}$, and is marked by the dashed lines

(Table 4). The steady state htpG expression level during nitrogen limitation was less than $50 \%$ of that during carbon limited growth, while the value obtained for the complex medium was similar to that for carbon limitation. To check whether the former was a function of the total cellular protein content, these were measured and found to be $62 \%$ under carbon limitation, $47 \%$ under nitrogen limitation and $59 \%$ in the complex medium.

The amount of $\beta$-galactosidase formed during the 10-min heat shock did not show any pronounced difference between carbon and nitrogen limitation as might have been expected from the steady state values (Table 4). In contrast, in complex medium $40 \%$ more $\beta$-galactosidase was formed than in carbon limited medium, although steady state htpG expression levels shown in Table 4 were essentially identical.

After returning the culture from the heat shock temperature to the normal growth temperature, large differences between both observed and expected values for the half life times of the $\beta$-galactosidase fusion protein were obtained as shown in Table 2.

\section{Discussion}

The steady state htpG expression levels observed at different temperatures were consistent with the relative intracellular levels of the C62.5 heat shock protein reported by Herendeen et al. (1979) for exponentially growing batch cultures of Escherichia coli at corresponding temperatures. Different growth limitations resulted in marked changes in the specific htpG expression during steady state growth and this result is qualitatively consistent with the reduction in the total protein content. Schultz et al. (1988) have shown that during nitrogen starvation the intracellular levels of some heat shock proteins in E. coli change. For example, the DnaK level increases during nitrogen starvation whilst GroEL is not even induced. However, nitrogen starvation, where no growth takes place, is an entirely different physiological state from nitrogen limited growth.
Table 4. Effect of growth medium composition on steady state and heat shock induced specific htpG gene expression expressed as specific $\beta$-galactosidase activity in $E$. coli at a dilution rate of $0.41 \mathrm{~h}^{-1}$. The growth and heat shock temperatures were 37 and $42^{\circ} \mathrm{C}$ respectively, heat shock exposure was $10 \mathrm{~min}$

\begin{tabular}{llll}
\hline & \multicolumn{3}{l}{$\begin{array}{l}\text { Specific } \beta \text {-galactosidase activity } \\
{\left[\Delta \mathrm{OD}_{420} / \mathrm{g}_{\text {cells }} \cdot \mathrm{min}\right]}\end{array}$} \\
\hline Growth medium & $\begin{array}{l}\text { Carbon- } \\
\text { limited }\end{array}$ & $\begin{array}{l}\text { Nitrogen- } \\
\text { limited }\end{array}$ & $\begin{array}{l}\text { Complex- } \\
\text { medium }\end{array}$ \\
\hline $\begin{array}{l}\text { Steady state level (A) } \\
\begin{array}{l}\text { Increase during } \\
10 \text { min heat shock (B) }\end{array}\end{array}$ & 1503 & 700 & 1508 \\
\begin{tabular}{l} 
Ratio (A/B) \\
\hline
\end{tabular} & 313 & 267 & 438 \\
\hline
\end{tabular}

Higher specific growth rates of $E$. coli in carbon limited medium resulted in a slight decrease of the specific $\beta$-galactosidase activity, which is in contrast to the results obtained by Pedersen et al. (1978) for the C62.5 protein levels at different growth rates in exponentially growing batch cultures. These authors reported a positive but nonproportional relationship between specific growth rate and C62.5 level, for experiments under entirely different conditions where various specific growth rates were established by changing the medium composition.

In our experiments the effect of the growth medium on htpG expression during a heat shock could not be predicted from steady state data. The increase in the specific $\beta$-galactosidase level under nitrogen limited growth was only $15 \%$ less than under carbon limitation despite entirely different steady state levels. The fact that under both limitations free amino acid pools are not markedly different in gram-negative bacteria (Tempest et al. 1970) gives a possible explanation for the similar heat shock protein synthesis rates during such short term heat shocks. Further, the response in complex medium, which was more pronounced than under carbon limitation, could result from an increased availability of metabolites. An increase in the extracellular amino acid concentration has been shown to increase the intracellular amino acid pool levels in E. coli (Britten and McClure 1962).

The expression of the htpG gene during a 10-min heat shock was regulated proportionally to the steady state levels at the different dilution rates investigated. This indicates that the bacterial cell is able to exhibit a similar heat shock response over a wide range of dilution rates under glucose limiting growth conditions. In contrast, under starvation conditions during the stationary phase of a batch culture, only a very reduced htpG gene expression was observed under identical heat shock conditions (Heitzer 1990). When the culture was returned after a heat shock to the initial growth temperature of $37^{\circ} \mathrm{C}$, an immediate reduction in the $\beta$-galactosidase synthesis rate was observed, irrespective of the growth conditions. This indicates a close and rapid temperature dependent regulation of htpG gene expression. The subsequent reduction of the intracellular heat shock protein level to the original level and the discrepancy between 
observed and expected dilution rate dependent half life times can be accounted for by at least two mechanisms. Firstly, overall proteolytic activity has been shown to increase in cells in which the heat shock response has been induced and moreover, one of the heat shock proteins, Lon, is known to be an important protease, specifically attacking abnormal and incomplete proteins (Goff et al. 1984; Goff and Goldberg 1985; Straus et al. 1988). Secondly, the original assumption of rapid return of the htpG gene expression immediately after a heat shock to the pre-heat shock synthesis rate might be invalid, and instead a transiently lower expression level might occur.

A final important question arising from these results concerns the mechanistic molecular basis for the regulation of htpG gene expression during both, steady and transient state under different growth conditions. Since the level of active $\sigma^{32}$, the product of the $\mathrm{rpoH}$ gene, limits transcription of heat shock genes (Tilly et al. 1989), the htpG gene expression will also depend on the regulation of the $\sigma^{32}$ concentration. However, the issue is nontrivial since the expression of the rpoH gene in $E$. coli is a complex process involving a multiple promoter system (Erickson et al. 1987; Fujita and Ishihama 1987) and these promoters have been shown to be differently and differentially regulated (Erickson et al. 1987; Ueshima et al. 1989; Wang and Kaguni 1989a, 1989b; Nagai et al. 1990). Further, the stability of $\sigma^{32}$ has been shown to be temperature dependent (Tilly et al. 1989). However, it is not known how different growth conditions affect these individual processes. The fact that under other stress conditions only subsets of these heat shock proteins are induced (Lindquist 1986) indicates that regulation other than only by $\sigma^{32}$ concentration at the transcription level of the individual heat shock proteins probably plays an important role.

\section{Conclusions}

The application of continuous culture techniques has been shown to be a valuable tool for investigating htpG heat shock gene expression under various controlled growth conditions. The results indicate that in addition to temperature as the major regulatory parameter of $h t p G$ expression, other growth environment dependent parameters clearly affect both steady and transient state expression.

\section{References}

Bardwell JCA, Craig EA (1987) Eucaryotic $\mathrm{M}_{\mathrm{r}} .83000$ heat shock protein has a homologue in Escherichia coli. Proc Natl Acad Sc1 USA 84:5177-5181

Bardwell JCA, Craig EA (1988) Ancient heat shock gene is dispensable. J Bacteriol 170:2977-2983

Britten RJ, McClure FT (1962) The amıno acid pool in Escherichia coli. Bacteriol Rev 26:292-335

Cowing DW, Bardwell JCA, Craig EA, Woolford C, Hendrix RW, Gross CA (1985) Consensus sequence for Escherichia coli heat sbock gene promoters. Proc Natl Acad Sci USA 82:2679- 2683
Erickson JW, Vaughn V, Walter WA, Neidhardt FC, Gross CA (1987) Regulation of the promoters and transcripts of rpoH, the Escherichia coli heat shock regulatory gene. Genes Dev $1: 419-432$

Evans CGT, Herbert T, Tempest DW (1970) The continuous cultivation of microorganisms. In: Norris JR, Ribbons DW (eds) Methods in microbiology, vol 2. Academic Press, London, pp 277-327

Fujita N, Ishihama A (1987) Heat shock induction of RNA polymerase sigma-32 synthesis in Escherichla coli: Transcriptional control and a multiple promoter system. Mol Gen Genet $210: 10-15$

Goff SA, Goldberg AL (1985) Production of abnormal proteins in $E$. colt stimulates transcription of lon and other heat shock genes. Cell $41: 587-595$

Goff SA, Casson LP, Goldberg AL (1984) Heat shock regulatory gene htpR influences rates of protein degradation and expression of the lon gene in Escherichia coli. Proc Natl Acad Sci USA $81: 6647-6651$

Goloubinoff P, Gatenby AA, Lorimer GH (1989) GroE heat shock proteins promote assembly of foreign procaryotic ribulose bisphosphate carboxylase oligomers in Escherichia coli. Nature $337: 44-47$

Grossman AD, Erickson JW, Gross CA (1984) The htpR gene product of $E$. coli is a sigma factor for heat shock promoters. Cell 38:383-390

Heitzer A (1990) Kinetic and physiological aspects of bacterial growth at superoptimum temperatures. Dissertation ETH No. 9217, Zürich

Heitzer A, Hamer G (1990) Recovery of exponentially growing cultures of Klebsiella pneumoniae NCIB 418 after heat shocks. Arch Microbiol 153:272-275

Herendeen SL, Van Bogelen RA, Neidhardt FC (1979) Levels of major proteins of Escherichia coli during growth at different temperatures. J Bacteriol 139:185-194

Lindquist S (1986) The heat shock response. Annu Rev Biochem 55:1151-1191

Miller JH (1972) Experiments in molecular genetics. Cold Spring Harbor Laboratory, Cold Spring Harbor, NY, p 431

Munkres KD, Richards FM (1965) The purification and properties of Neurospora malate dehydrogenase. Arch Biochem Biophys 109:466-479

Nagai H, Yano R, Erickson JW, Yura T (1990) Transcriptional regulation of the heat shock regulatory gene rpoH in Escherichia coli: Involvement of a novel catabolite-sensitive promoter. J Bacteriol 172:2710-2715

Neidhardt FC, Van Bogelen RA (1981) Positive regulatory gene for temperature-controlled proteins in Escherichia coli. Biochem Biophys Res Commun 100:894-900

Neidhardt FC, Van Bogelen RA (1987) Heat shock response. In: Neidhardt FC (ed) Escherichia coli and Salmonella typhimurium: cellular and molecular biology, vol 2. American Society for Microbiology, Washington, DC, pp 1334-1345

Neidhardt FC, Van Bogelen RA, Vaughn V (1984) The genetics and regulation of heat shock proteins. Annu Rev Genet 18:295329

Pedersen S, Bloch PL, Reeh S, Neidhardt FC (1978) Patterns of protein synthesis in $E$. coli: a catalog of the amount of 140 individual proteins at different growth rates. Cell 14:179190

Raina S, Georgopoulos C (1990) A new Escherichia coli heat shock gene, htrC, whose product is essential for viability only at high temperatures. J Bacteriol 172:3417-3426

Schultz JE, Latter GI, Matin A (1988) Differential regulation by cyclic AMP of starvation protein synthesis in Escherichia coli. J Bacteriol 170:3903-3909

Straus DB, Walter WA, Gross CA (1988) Escherichia coli heat shock gene mutants are defective in proteolysis. Genes Dev 2:18511858

Tempest DW, Meers JL, Brown CM (1970) Influence of environment on the content and composition of microbial free amino acid pools. J Gen Microbiol 64.171-185 
Tilly K, Spence J, Georgopoulos C (1989) Modulation of stability of the Escherichia coli heat shock regulatory factor $\sigma^{32}$. J Bacteriol $171: 1585-1589$

Tsuchido T, Van Bogelen RA, Neidhardt FC (1986) Heat shock response in Escherichia coli concerns cell division. Proc Natl Acad Sci USA 83:6959-6963

Ueshima R, Fujita N, Ishihama A (1989) DNA supercoiling and tempeature shift affect the promoter activity of Escherichia coli $\mathrm{rpoH}$ gene encoding the heat shock sigma subunit of RNA polymerase. Mol Gen Genet 215:185- 189

Van Dyk TK, Gatenby AA, LaRossa RA (1989) Demonstration by genetic suppression of interaction of GroE products with many proteins. Nature 342:451-453
Wang Q, Kaguni JM (1989a) A novel sigma factor is involved in expression of the rpoH gene of Escherichia coli. J Bacteriol $171: 4248-4253$

Wang Q, Kaguni JM (1989b) dnaA protein regulates transcription of the rpoH gene of Escherichia coli. J Biol Chem 264:73387344

Yamamori T, Yura T (1982) Genetic control of heat shock protein synthesis and its bearing on growth and thermal resistance in Escherichia coli K-12. Proc Natl Acad Sci USA 79:860864 